\title{
Correction to: Porcine small intestinal organoids as a model to explore ETEC-host interactions in the gut
}

\author{
Bjarne Vermeire ${ }^{1}$ (D), Liara M. Gonzalez ${ }^{2}$, Robert J. J. Jansens ${ }^{1}$, Eric Cox ${ }^{1}$ and Bert Devriendt ${ }^{*}$
}

\section{Correction to: Vet Res (2021) 52:94 \\ https://doi.org/10.1186/s13567-021-00961-7}

Following publication of the original article [1], we have been informed that Figure $2 \mathrm{~B}$ and $\mathrm{C}$ needs to be updated. In the midpanel, the y-axis labeling is partially visible but should not have been visible. The updated figure is given below.

The original article has been corrected.

\footnotetext{
(See figure on next page.)
}

Figure 2 Porcine enteroids mimic the response of the small intestine to ETEC-derived enterotoxins. Spheroids derived from duodenum, jejunum and ileum 6 days after passaging were stimulated with enterotoxins or guanylin and imaged using live-cell microscopy. The surface area of the spheroids was measured using ImageJ. A Representative images displaying ileal spheroid swelling induced by guanylin (10 $\mu \mathrm{M})$ at T0, T50 and T1 10 upon administration. B, C The average relative area increase of the spheroids was plotted in function of the time after enterotoxin administration. ( $\mathrm{n}=3$ for all tissues). D Spheroid bursting upon guanylin $(10 \mu \mathrm{M})$ stimulation. Images are representative for other tissues and swelling inducers. Scale bar $=100 \mu \mathrm{m}$. Relative IL8 secretion in medium supernatant (E) and Matrigel dome (F) of jejunal enteroids stimulated for $24 \mathrm{~h}$ with bacterial supernatant with (WT) or without enterotoxins (toxin negative) compared to non-immunogenic guanylin ( $\mathrm{n}=3$; Kruskal-Wallis test).

The original article can be found online at https://doi.org/10.1186/s13567021-00961-7.

*Correspondence: b.devriendt@ugent.be

1 Department of Virology, Parasitology, Immunology, Faculty of Veterinary

Medicine, Laboratory of Immunology, Ghent University, 9820 Merelbeke, Belgium

Full list of author information is available at the end of the article original author(s) and the source, provide a link to the Creative Commons licence, and indicate if changes were made. The images or other third party material in this article are included in the article's Creative Commons licence, unless indicated otherwise in a credit line to the material. If material is not included in the article's Creative Commons licence and your intended use is not permitted by statutory regulation or exceeds the permitted use, you will need to obtain permission directly from the copyright holder. To view a copy of this licence, visit http://creativecommons.org/licenses/by/4.0/. The Creative Commons Public Domain Dedication waiver (http://creativeco mmons.org/publicdomain/zero/1.0/) applies to the data made available in this article, unless otherwise stated in a credit line to the data. 


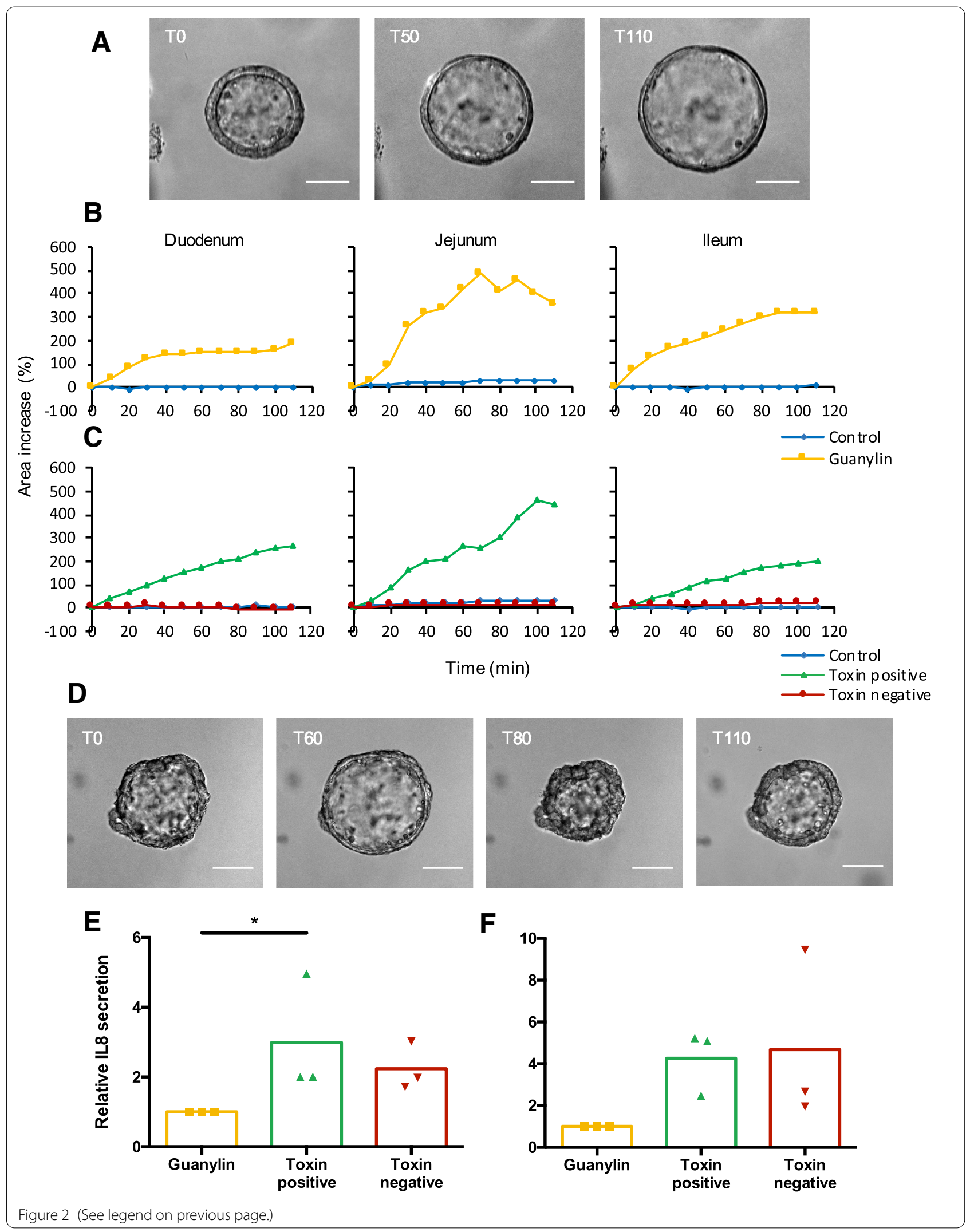




\section{Author details}

${ }^{1}$ Department of Virology, Parasitology, Immunology, Faculty of Veterinary Medicine, Laboratory of Immunology, Ghent University, 9820 Merelbeke, Belgium. ${ }^{2}$ Laboratory of Intestinal Regenerative Medicine, College of Veterinary Medicine, NCSU, Raleigh, NC, USA.

Published online: 03 August 2021

\section{Reference}

1. Vermeire B, Gonzalez LM, Jansens RJJ, Cox E, Devriendt B (2021) Porcine small intestinal organoids as a model to explore ETEC-host interactions in the gut. Vet Res 52:94. https://doi.org/10.1186/s13567-021-00961-7

\section{Publisher's Note}

Springer Nature remains neutral with regard to jurisdictional claims in published maps and institutional affiliations. 